\title{
Quantification of the quality problems in the construction machinery production
}

\author{
Renata Stasiak-Betlejewsk ${ }^{1, *}$ and Agnieszka Czajkowska ${ }^{2}$ \\ ${ }^{1}$ Institute of Production Engineering, Faculty of Management, Częstochowa University of \\ Technology, Poland \\ ${ }^{2}$ Department of Strength of Materials, Concrete Structures and Bridges, Faculty of Civil Engineering \\ and Architecture, Kielce University of Technology, Poland
}

\begin{abstract}
Paper presents results of the research findings on the quality problems analysis conducted in the chosen enterprise producing a machinery for the construction industry. The aim of the study was to identify the causes and consequences of the quality problems in the production by using selected methods and tools of the quality management, as well as to identify opportunities to minimize the existing risks in the production process. The results show that approximately $77 \%$ of production losses are caused by incompatibilities resulting from two quality problems caused by employee errors and the low quality level of supplied screw taps. The results of the study indicate the corrective measures that may be taken in the company in order to eliminate and reduce identified production problems contributing to the production of machines that do not meet building standards.
\end{abstract}

\section{Introduction}

The construction machines industry in Poland experienced the biggest boom in the 70's and 80 's and afterwards there was a collapse in the early 90 s around the world noted the significant decline in a demand for all kinds of cranes, excavators, bulldozers and more specialized equipment [1]. Polish construction industry crisis has been stopped in 1994, when the statistics show the construction machines production increase by more than $30 \%$ annually. Polish construction industry has undergone the structural transformation. Some manufacturers has started to certify their products with ISO 9000 (PN-EN-29000).

The fulfilment of European standards is important to approximate the technicaloperational parameters of the construction machinery. Currently, the construction machines users pay special attention to the following factors such as: a safety, a quality and environmental operating conditions and the need to meet the requirements of ergonomic work (i.e. human factors). The first two requirements are governed by the relevant European standards EN and ISO. Environmental performance of the machines driving machines is regulated by the strict Euro II Directive since January 1996. Regulations on human factors (HF), which include among others: noise, vibration and ergonomics of the machine, are more complex. Cushioned cabin of materials absorbing a part of the vibration

${ }^{*}$ Corresponding author: renatastasiak@wp.pl 
energy seats is matched to the shape of the human body is only one of several means already used on a large scale.

Polish construction industry includes almost 140 plants of various sizes, employing some 50,000 workers. The sale of the construction machinery, including the road construction, is now about $10 \%$ of total sale in Polish engineering industry. Turnover of this sector since the early 90's steadily growing and it is estimated to exceed 500 million USD. Resources domestic construction machinery market consists of about 60000 of the machinery and equipment - including about 10000 of the mobile cranes, 11000 of excavators, 10000 of the cat track and 3000 of the wheel loaders. About half of these devices was manufactured before 1997, 40\% - in 1997-2000, 30\% - in 2001-2005. Machinery and equipment imports constitute about $70 \%$ of the total construction machinery number. In the foreign observers' opinion, Polish construction machines and equipment are competitive in terms of the quality and the price $[2,3]$.

The growing number of the road construction and the boom in the construction industry involves more the heavy construction machines and the equipment. There is also much smaller machinery and equipment involved in the completion of the road construction investment such as the plate compactors. The plate compactors are particularly suitable for the soil consolidation in a rather wide pits, but also a surfactant. It is also applied successfully for compacting asphalt and paving of cobblestones [2].

The aim of the paper is analysis of the quality problems identified in the manufacturing of the plate compactors machines. Obtained research findings have been analysed with the quality management tools and quality management method (Ishikawa diagram, Pareto Lorenz diagram and FMEA method) applying to identify the most significant problems in the manufacturing process to improve the final quality of the plate compactors used in the road construction investments.

\section{Characteristics of the research object}

The research on the plate compactors manufacturing was conducted in the chosen Polish construction machine manufacturing enterprise. The plant is engaged in designing and manufacturing of small machines and equipment for the construction industry, repair and maintenance of the roads. Currently the company offers 14 different products, including 9 types of the soil plate compactors, 2 types of the surface cutters, the slurry pump with the combustion engine, a generator and a concrete cutter profiles. The study was discussed the petrol plate compactor ZGS-12/500 that is used to vibratory compaction, e.g. sand, gravel, asphalt or paving stones.

\subsection{The quality issues in the analysed enterprise manufacturing profile}

The analysed enterprise is the innovative and technical Polish enterprise that was established in 1987. Since the beginning of its activity it is engaged in designing and manufacturing of small and medium-sized machinery and equipment for construction, repair and maintenance of roads. The subject of the research conducted in the analysed enterprise is the petrol plate soil compactor type ZGS-12/500 that was designed by the enterprise. The machine consists of a number of assemblies, subassemblies and components, which are made of different grades of steel, epoxy resins and elastomeric components. Compactor type ZGS-12/500 is used to work on the road construction and repair of roads, the laying of pavements, car parks, squares, sports fields, compaction of narrow trenches in industrial and hydraulic engineering. Due to the large decrease in efficiency and effectiveness, it is pointless to use it, the share of clay fraction exceeds $10 \%$, a fraction of dust is greater than $30 \%$. Through the use of special plates elastomer, which is 
an accessory, there is a possibility of levelling the pavement and concrete blocks. Compactor provides immediate stabilization of the soil and it help to obtain the surface durability. The petrol plate compactor analysed in the paper is presented in Figure 1.

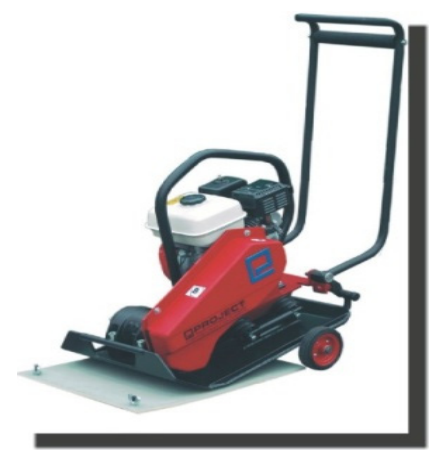

Fig. 1. The petrol plate compactor type ZGS-12/500.

The liability for the quality of the product and its components occurring in the manufacturing process is provided by the Quality Controller and Representative of the Enterprise Quality System. The control process of the production process is described in the Technical Conditions. There are also specific control methods at the various stages of the process. The whole quality control process and its components are strictly inscribed in the Quality Assurance System as described in the corresponding Procedures. The materials used for the production of individual parts of the plate compactor should comply with the technical documentation and material standards (important quality feature of the plate compactor is that castings made of gravy cast iron shall comply with BN74/19046-04 standard and dimensions of parts, assemblies and complete compactors for which to design drawings not specified dimensional tolerances should be done in 13 accuracy class according to PN-79/M-02139 standard). Another important quality feature of the plate compactor are screw connections that should be tightened by hand or mechanically correct key. The size of allowable tightening torques should comply with PN-81/M-82056 standard with a maximum tolerance of $10 \%$. Bolted connections should be secured against selfloosening in accordance with the technical documentation. Welded joints should be consistent with the requirements of BN-73/1610-1603 standard. Every compactor should be tested (uptime during the test shall be 15 minutes) to check the correct operation of the machine and all cooperating assemblies and components. There are tested: correct function of the speed and the engine start, turnover inclusion centrifugal clutch, rated speed of the engine $(\mathrm{DTR}=3600 \mathrm{rev} / \mathrm{min})$, the rate of entry into the cold vibrator turn (tdop $=10 \mathrm{~s}$ ), operating temperature of the vibrator (at the end of the test should not exceed $95^{\circ} \mathrm{C}$ ), any grease leaks, any metallic rattles and creaks during operation, $\mathrm{CO}$ content in the exhaust gas (perm. content $<4.5 \%$ ). The critical quality feature of the plate compactor quality is related to the issue of the protection against corrosion. All connecting elements (screws, bolts, nuts, washers, pins and steel components) specified in the design documentation must be protected against corrosion by galvanizing. The surfaces to be coated should be proportionate to the degree of purity B2a in accordance to PN-70/H-97050 standard. Lacquered surfaces should be covered with a layer of a pre-primer. Cover painted shall meet the conditions workmanship min. 3 class according to PN-79/H-97070 standards. All painted surfaces should be covered with double layer of varnish $[4,5]$. 


\section{Research findings and discussion}

In recent times, the main problem occurring in the enterprise is a production losses increase. In order to identify and systematize the causes of manufacturing problem there was created Ishikawa diagram with using the brainstorming method. There were identified five manufacturing causes areas i.e.: 'materials', 'machine', 'method', 'man', 'organization' (Fig. 2). Analysing data presented in the Ishikawa diagram (Fig. 2), it can be stated that 'man' and 'method' areas generated the majority of the manufacturing problems. Improper personnel policy was identified as the main problem cause that is linked with quality issues performance in the analysed enterprise.

Research findings presented in the Ishikawa diagram (Fig. 2) also allows linking of the manufacturing losses increase with the following reasons causing this situation:

-company seeking to reduce the production costs has decided to change supplier of taps on the supplier offering a lower price (however this change, despite the fact that led to the restrictions mentioned above costs, is the main reason for picking threads and making losses);

-a very important factor is partly used machinery;

-persons employed directly at the production process does not comply with the quality standards;

-the lack of a smooth flow of information between the different levels of the manufacturing process;

-poor application of technology, particularly in the manufacturing of new products.

In order to identify the significant factors affecting the final quality problems occurring in the construction machines manufacturing process the Pareto - Lorenz diagram was applied to evaluate the hierarchy of the manufacturing incompatibilities in the plate compactor manufacturing. Pareto - Lorenz analysis is carried out to identify and to establish the hierarchy of the incompatibilities identified in the manufacturing process. Research results are used to elaborate the corrective and preventive actions for the production process within the quality issues on the analysed product [6 - 8].

In order to arrange the causes of production losses in terms of their frequency they were carried out analysis of Pareto-Lorenz. Authors identified the following causes of the manufacturing process losses as the following incompatibilities:

N1 - poorly bent shaft;

N2 - unevenly welded worktop;

N3 - broken threads in the mounting vibrator;

$\mathrm{N} 4$ - damaged paint cover of the engine plates;

N5 - improper angle of the shaft.

The frequency of incompatibilities' occurrence in the analysed enterprise in 2014 and the cumulative percentage of identified incompatibilities were presented in Table 1 and Figure 3.

Analysing data presented in Figure 3, it can be stated that over 77\% of incompatibilities are caused by two causes (N4 and N3). Reduction of the production losses and thereby the enterprise profits increase can be achieved by eliminating of the failures in the engine plate painting and searching supplier of the highest quality taps. Acquisition of the low quality sheets and pipes happens occasionally, which it is certainly a result of long-term relationships with reliable suppliers. Cause like poorly bent shaft due to the rarity of its occurrence has little effect on the resulting waste. 


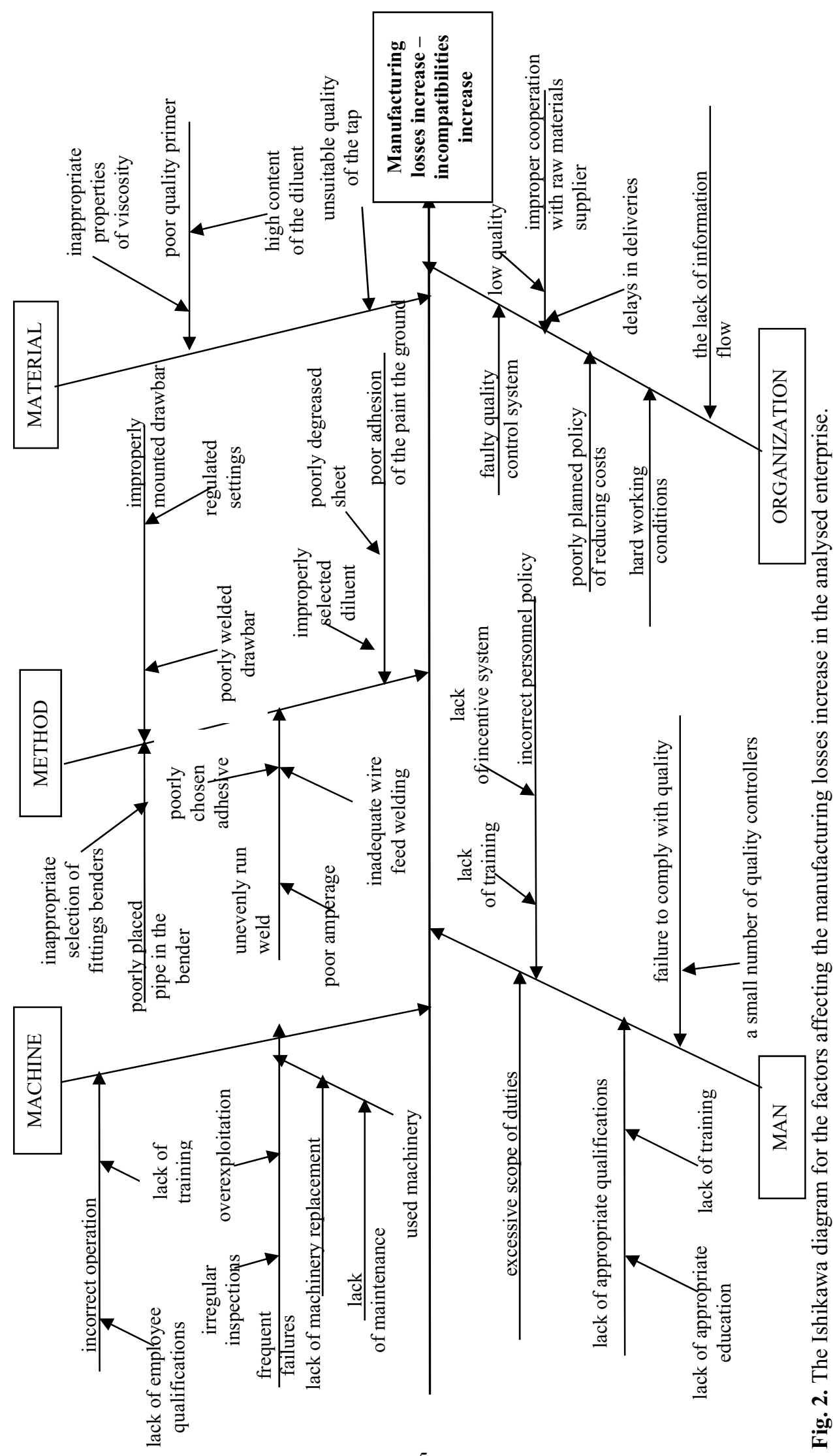


Table 1. Incompatibilities identified in the petrol plate compactor manufacturing process in the analysed enterprise in 2014.

\begin{tabular}{|c|c|c|c|c|}
\hline $\begin{array}{c}\text { Denotation } \\
\text { of the } \\
\text { incompatibility }\end{array}$ & $\begin{array}{l}\text { The name of the } \\
\text { incompatibility }\end{array}$ & \begin{tabular}{|c|} 
The frequency \\
of \\
incompatibilities \\
occurrence in \\
the research \\
period
\end{tabular} & \begin{tabular}{|c} 
The percentage \\
of \\
incompatibilities \\
{$[\%]$} \\
\end{tabular} & $\begin{array}{c}\text { The cumulative } \\
\text { percentage } \\
\text { of } \\
\text { incompatibilities } \\
\text { [\%] }\end{array}$ \\
\hline $\mathrm{N} 4$ & $\begin{array}{l}\text { damaged paint cover } \\
\text { of the engine plates }\end{array}$ & 39 & 50,65 & 50,65 \\
\hline N3 & $\begin{array}{l}\text { broken threads in the } \\
\text { mounting vibrator }\end{array}$ & 21 & 27,27 & 77,92 \\
\hline N5 & $\begin{array}{l}\text { improper angle of the } \\
\text { shaft }\end{array}$ & 9 & 11,69 & 89,61 \\
\hline $\mathrm{N} 2$ & $\begin{array}{l}\text { unevenly welded } \\
\text { worktop }\end{array}$ & 5 & 6,49 & 96,10 \\
\hline N1 & poorly bent shaft & 3 & 3,90 & 100 \\
\hline & Total & 77 & 100 & \\
\hline
\end{tabular}

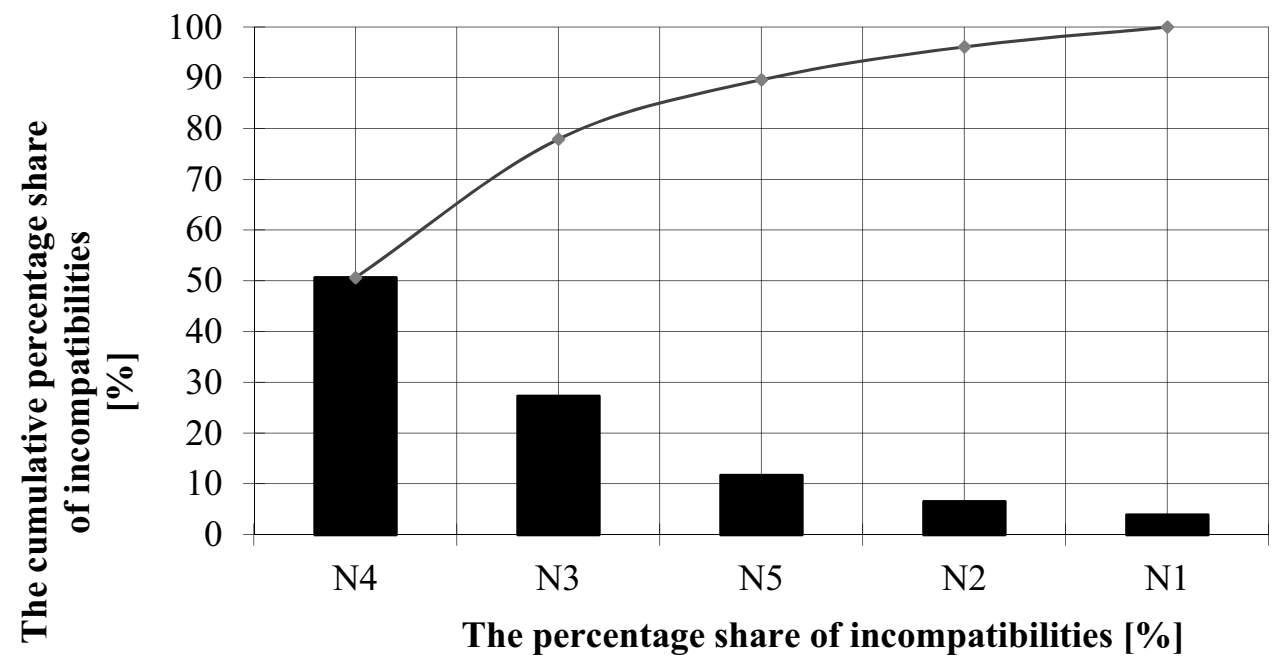

Fig. 3. Pareto-Lorenz diagram for the incompatibilities identified in the petrol plate compactor manufacturing process in the analysed enterprise in 2014.

Failure Modes and Effects Analysis (FMEA) method was applied in order to analyse possible failures, their causes and effects of identified incompatibilities in the petrol plate compactor manufacturing process. This method requires defining the relationship causeeffect-defect by scoring points on a scale $1 \div 10$ due to three criteria: the risk of defects 
appearance (R), the probability of defects detecting (W), the importance of defect appearance $(Z)$. The product of these three values multiplying is called the priority number $\mathrm{P}$, which is as a measure of the validity of individual failures and it provides the basis for their hierarchy. Priority number of the Risk (LPR) accounts according to the formula: LPR $=\mathrm{LPW} \times \mathrm{LPZ} \times$ LPO (1) where: LPW - Priority Number of Appearing. LPZ - Priority Number of Meaning (for customer). LPO - Priority Number of Detectability [6, 9].

Table 2 presenting the graduating system in the research findings analysis was applied in order to elaborate results for table 3 .

Table 2. Scale of grading R, W, Z in FMEA method.

\begin{tabular}{|c|c|c|c|c|c|c|}
\hline No & \multicolumn{2}{|c|}{$\begin{array}{c}\text { Risk of defects appearance } \\
\text { (R) }\end{array}$} & \multicolumn{2}{c|}{$\begin{array}{c}\text { Probability } \\
\text { of defects detecting (W) }\end{array}$} & \multicolumn{2}{c|}{ Effects/meaning of defects (Z) } \\
\hline 1 & Unlikely & 1 & High & 1 & Hardly perceptible & 1 \\
\hline 2 & Very unlikely & $2-3$ & Moderate & $2-5$ & Few perceptible & $2-3$ \\
\hline 3 & Unlikely & $4-6$ & Low & $6-8$ & $\begin{array}{c}\text { Moderately } \\
\text { perceptible }\end{array}$ & $4-6$ \\
\hline 4 & Moderately likely & $7-8$ & Very low & 9 & Hardly perceptible & $7-8$ \\
\hline 5 & High probability & $9-10$ & Impossible & 10 & $\begin{array}{c}\text { Very strongly } \\
\text { perceptible }\end{array}$ & $9-10$ \\
\hline
\end{tabular}

Identifying quality problems in the manufacturing process (Table 3) allows using of preventive measures, implementing of corrective actions and testing their effectiveness. Quality problems, which are the source of the greatest threats, should be solved as the first step. Table 3 describes the preventive measures for the failures occurrence. The technology change is the key factor in this step since the improper technology increases production losses. There are suggested also staff training which is why the company's management should focus on elaborating of the training system for employees.

An important factor in the production process is also used machinery, which is why the company should pay attention to more frequent inspections of the equipment, as well as reflect on the partial replacement of the machine park. For this company the majority of the faults and their causes are adequately easily detectable, and therefore should be already in the design phase the production of all identify them and take any action that will ensure that the probability of failures and thus the number of risk will be minimized. This is in line with the motto FMEA method, which reads: "prevent the emergence of errors rather than detection."

As Table 3 shows the introduction of any corrective measures led to a significant reduction in the number of risk for individual failures. An analysis of incompatibilities carried out by using Pareto-Lorenz diagram shows that over $77 \%$ production loss is caused by two incompatibilities (damaged paint cover of the engine plate and broken threads in the mounting vibrator). The first one is caused by the most common workers' failure while the second - the poor quality of supplied taps. 
Table 3. FMEA method for defects identified in the petrol plate compactor manufacturing process in the analysed enterprise in 2014.

\begin{tabular}{|c|c|c|c|c|c|c|c|c|c|c|c|c|}
\hline $\begin{array}{c}\text { Name of } \\
\text { defect }\end{array}$ & $\begin{array}{c}\text { The } \\
\text { location } \\
\text { of the } \\
\text { defect }\end{array}$ & Cause & Effect & $\mathrm{R}$ & W & Z & $\mathrm{P}$ & $\begin{array}{c}\text { Corrective } \\
\text { actions }\end{array}$ & $\mathrm{R}$ & $\mathrm{w}$ & Z & $\mathrm{P}$ \\
\hline $\begin{array}{l}\text { damaged } \\
\text { paint cover } \\
\text { of the } \\
\text { engine } \\
\text { plates }\end{array}$ & 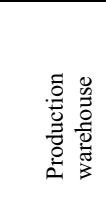 & $\begin{array}{l}\text { poor quality } \\
\text { primer, } \\
\text { improperly } \\
\text { degreased } \\
\text { sheet }\end{array}$ & $\begin{array}{l}\text { waste, } \\
\text { complaint, } \\
\text { return, } \\
\text { customer } \\
\text { dissatisfaction }\end{array}$ & 7 & 4 & 10 & 280 & $\begin{array}{l}\text { information } \\
\text { flow } \\
\text { improvement } \\
\text { training, } \\
\text { change } \\
\text { of the } \\
\text { supplier }\end{array}$ & 3 & 4 & 10 & 120 \\
\hline $\begin{array}{l}\text { broken } \\
\text { threads in } \\
\text { the } \\
\text { mounting } \\
\text { vibrator }\end{array}$ & 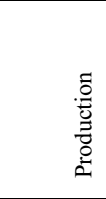 & $\begin{array}{l}\text { worker's } \\
\text { failure, } \\
\text { poor quality } \\
\text { of the tap }\end{array}$ & waste & 8 & 3 & 8 & 192 & $\begin{array}{l}\text { change } \\
\text { of the } \\
\text { supplier, } \\
\text { change } \\
\text { of the } \\
\text { technology, } \\
\text { training }\end{array}$ & 5 & 2 & 8 & 80 \\
\hline $\begin{array}{l}\text { improper } \\
\text { angle of } \\
\text { the shaft }\end{array}$ & 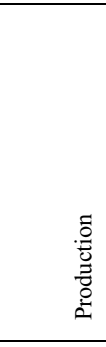 & $\begin{array}{l}\text { worker's } \\
\text { failure, } \\
\text { breakdown } \\
\text { of the } \\
\text { machine, } \\
\text { improper } \\
\text { technology }\end{array}$ & $\begin{array}{l}\text { waste, } \\
\text { complaint, } \\
\text { return, } \\
\text { customer } \\
\text { dissatisfaction }\end{array}$ & 5 & 2 & 8 & 112 & $\begin{array}{l}\text { information } \\
\text { flow } \\
\text { improvement } \\
\text { training, } \\
\text { changes in } \\
\text { production } \\
\text { technology, } \\
\text { more } \\
\text { frequent } \\
\text { inspections } \\
\text { of machines } \\
\end{array}$ & 3 & 2 & 8 & 48 \\
\hline $\begin{array}{l}\text { unevenly } \\
\text { welded } \\
\text { worktop }\end{array}$ & 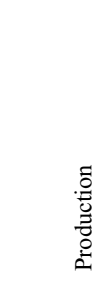 & $\begin{array}{l}\text { worker's } \\
\text { failure, } \\
\text { breakdown } \\
\text { of the } \\
\text { machine, } \\
\text { improper } \\
\text { technology }\end{array}$ & waste & 5 & 1 & 9 & 45 & $\begin{array}{l}\text { staff training, } \\
\text { change of the } \\
\text { technology, } \\
\text { quality } \\
\text { control } \\
\text { extension }\end{array}$ & 3 & 1 & 9 & 27 \\
\hline $\begin{array}{l}\text { poorly } \\
\text { bent shaft }\end{array}$ & 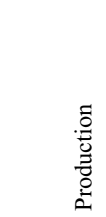 & $\begin{array}{l}\text { worker's } \\
\text { failure, } \\
\text { breakdown } \\
\text { of the } \\
\text { machine, } \\
\text { improper } \\
\text { technology }\end{array}$ & waste & 5 & 1 & 9 & 45 & $\begin{array}{l}\text { staff training, } \\
\text { changing } \\
\text { of the } \\
\text { technology }\end{array}$ & 2 & 1 & 9 & 18 \\
\hline
\end{tabular}

\section{Conclusion}

Analysis of the research findings and corrective and preventive actions obtained as the result of the applied quality management tools and method allows to summarize suggestions for the analysed enterprise manufacturing process:

-greater focus on "improving" their employees, the introduction of a workers training system, skills upgrading, which will reduce the number of mistakes made by the crew;

-consider the possibility of changing taps' supplier;

-the production technology improvement;

-the information flow improvement both between employees and their superiors, and between different departments in the company; 
-intensified control measures.

Another important factor contributing to the improvement of the production process in the analysed enterprise is machines capacity utilization level increase, which will ensure increase in production, as well as reducing maintenance costs of the equipment.

\section{References}

1. Report Polish Roads, January (2007)

2. Report News of the building technique, June (2008)

3. Report Construction, maintenance and operation, (2007)

4. P.I.T. Project technical conditions, ZGS-12

5. S. Borkowski, J. Selejdak, Sz. Salamon, Efektywność eksploatacji maszyn i urzadzeń, (Czestochowa University of Technology, Częstochowa,2007).

6. S. Borkowski, Mierzenie poziomu jakości, (Higher School of Management and Marketing, Sosnowiec, 2004)

7. J. Bank, Zarzadzanie przez jakość, (Gebethner i S-ka, Warszawa, 1996)

8. L. Costinescu, C. Cojocariu, M. Dudiţa, L. Parv, I.L. Velicu, D. Munteanu. JOAM, 17, 1-2, (2015)

9. L. Parv. Data management in innovative engineering (Transilvania University Publishing House, 2015) 